\author{
Sławomir Kasperczyk \\ Michał Dobrakowski ${ }^{1}$ \\ Janusz Kasperczyk $k^{2}$ \\ Ewa Romuk ${ }^{1}$ \\ Adam Prokopowicz \\ Ewa Birkner ${ }^{1}$
}

\title{
THE INFLUENCE OF $\beta$-CAROTENE ON HOMOCYSTEINE LEVEL AND OXIDATIVE STRESS IN LEAD-EXPOSED WORKERS
}

\author{
WPŁYW $\beta$-KAROTENU NA STĘŻENIE HOMOCYSTEINY I NASILENIE STRESU OKSYDACYJNEGO \\ U PRACOWNIKÓW NARAŻONYCH NA ZWIAZZKI OŁOWIU
}

\begin{abstract}
${ }^{1}$ Medical University of Silesia / Śląski Uniwersytet Medyczny w Katowicach, Zabrze, Poland School of Medicine with the Division of Dentistry, Department of Biochemistry / Wydział Lekarski z Oddziałem Lekarsko-Dentystycznym, Katedra Biochemii

${ }^{2}$ Medical University of Silesia / Śląski Uniwersytet Medyczny w Katowicach, Zabrze, Poland School of Medicine with the Division of Dentistry, Department of Environmental Medicine and Epidemiology / Wydział Lekarski z Oddziałem Lekarsko-Dentystycznym, Katedra i Zakład Medycyny i Epidemiologii Środowiskowej

${ }^{3}$ Institute of Occupational Medicine and Environmental, / Instytut Medycyny Pracy i Zdrowia Środowiskowego, Sosnowiec, Poland Health Department of Chemical Hazards and Genetic Toxicology Zakład Szkodliwości Chemicznych i Toksykologii Genetycznej
\end{abstract}

\begin{abstract}
Background: Oxidative stress is involved in lead toxicity. This suggests that some antioxidants may play a role in the treatment of lead poisoning. In the light of this, the aim of the study was to determine whether $\beta$-carotene administration reduces oxidative stress and homocysteine level in workers chronically exposed to lead. Material and Methods: The exposed population included healthy male workers exposed to lead who were randomly divided into 2 groups (mean blood lead level ca. $44 \mu \mathrm{g} / \mathrm{dl}$ ). Workers in the $1 \mathrm{st}$ group ( $\mathrm{N}=49$, reference group) had no antioxidants, drugs, vitamins or dietary supplements administered, while workers in the $2 \mathrm{nd}$ group $(\mathrm{N}=33$ ) had $\beta$-carotene administered in a dose of $10 \mathrm{mg}$ per day for 12 weeks. Biochemical analysis included markers of lead-exposure and the level of malondialdehyde (MDA), an oxidative stress biomarker. We also measured the level of homocysteine (Hcy) and thiol groups as well as the activity of superoxide dismutase (SOD) and its isoenzyme EC-SOD in serum. Results: After supplementation, the level of MDA significantly decreased, compared to baseline, by $16 \%$, and to the reference group. When compared to the reference group, Hcy level was also significantly decreased. However, the level of thiol groups was significantly higher after supplementation with $\beta$-carotene compared to the reference group. Analogically, the activity of SOD and EC-SOD was significantly higher compared to the baseline and to the reference group. Conclusions: Despite some controversies over antioxidant properties of $\beta$-carotene, our results indicate that its antioxidant action could provide some beneficial effects in lead poisoning independent of chelation. Med Pr 2014;65(3):309-316
\end{abstract}

Key words: $\beta$-carotene, lead poisoning, oxidative stress, homocysteine

\section{STRESZCZENIE}

Wstęp: Ponieważ ołów wywołuje stres oksydacyjny, przypuszcza się, że antyoksydanty mogą mieć zastosowanie w leczeniu zatrucia tym metalem. Celem niniejszej pracy było zbadanie, czy podawanie $\beta$-karotenu redukuje stres oksydacyjny oraz obniża stężenie homocysteiny u pracowników narażonych na ołów. Materiał i metody: Grupę badaną stanowili zdrowi pracownicy płci męskiej podzieleni na 2 podgrupy (średnie stężenie ołowiu we krwi: ok. $44 \mu \mathrm{g} / \mathrm{dl}$ ). W pierwszej ( $\mathrm{N}=49$, grupa porównawcza) nie stosowano żadnego leczenia, a drugiej podawano $\beta$-karoten w dawce $10 \mathrm{mg}$ na dzień przez 12 tygodni. Analiza biochemiczna objęła markery narażenia na ołów i marker stresu oksydacyjnego - dialdehyd malonowy (malondialdehyde - MDA). Ponadto zbadano stężenie homocysteiny (homocysteine - Hcy), grup tiolowych oraz aktywność dysmutazy ponadtlenkowej (superoxide dismutase - SOD) i jej izoenzymu EC-SOD. Wyniki: Po suplementacji w grupie leczonej zaobserwowano obniżenie się stężenia MDA w porównaniu z wartościami wyjściowymi oraz z wynikami w grupie porównawczej. Obniżeniu uległo także stężenie Hcy w porównaniu z wynikami uzyskanymi dla grupy porównawczej. Z kolei stężenie grup tiolowych oraz aktywność SOD uległy zwiększeniu w porównaniu z grupą porównawczą, a w przypadku SOD i EC-SOD także w porównaniu z wartościami wyjściowymi. Wnioski: Wyniki niniejszego badania sugerują, że podawanie $\beta$-karotenu w zatruciu ołowiem może przynieść korzyści, takie jak zmniejszenie stresu oksydacyjnego, mierzonego pośrednio jako stężenie MDA, lub obniżenie stężenia aterogennej homocysteiny. Med. Pr. 2014;65(3):309-316

Słowa kluczowe: $\beta$-karoten, zatrucie ołowiem, stres oksydacyjny, homocysteina

Corresponding author / Autor do korespondencji: Sławomir Kasperczyk, Department of Biochemistry, Medical University of Silesia, Jordana 19, 41-808 Zabrze, Poland, e-mail: kaslav@mp.pl Received: 2013, November 10; accepted: 2014, January 24 


\section{INTRODUCTION}

Lead is one of the earliest metals discovered by the human race. Due to softness, high malleability, ductility, low melting point and resistance to corrosion, lead has many industrial applications. Widespread usage of lead and its accumulation in the environment make exposure to this xenobiotic unavoidable $(1,2)$. In Poland, there are approximately 26500 workers occupationally exposed to lead and only $76 \%$ of them are monitored for blood lead levels. Exposure of approximately 2000 persons exceeds the Polish MAC level of $0.050 \mathrm{mg} / \mathrm{m}^{3}$. Therefore, it is possible to state that occupational exposure to lead is still a vital problem in Polish industry (3).

A safe level of exposure to lead has not been defined. Data indicates that even low exposure to lead may induce cognitive dysfunction, neurobehavioral disorders, neurological damage, hypertension and renal impairment (4). Pathogenesis of lead poisoning is multifactorial and oxidative stress has been suggested to be one possible mechanism for its toxicity. Lead generates reactive oxygen species (ROS) directly or by up-regulating activity of xanthine oxidase $(\mathrm{XO})$ which generates superoxide anions (5). In addition, lead reduces antioxidant reserves. Having high affinity for thiol groups, lead depletes the level of glutathione, which is a major thiolcontaining antioxidant of the human body, and binds to the thiol groups of many enzymes. In consequence, lead disrupts the function of antioxidant enzymes, such as superoxide dismutase or catalase. Delta-aminolevulinic acid dehydratase (delta-ALAD) is a well-known enzyme that is also inhibited by lead. This inhibition results in the accumulation of delta-aminolevulinic acid (ALAD) which additively acts as a pro-oxidant $(1,6)$.

Several recent studies have reported that homocysteine (Hcy) concentration is believed to be increased in lead poisoning as well. Homocysteine level exceeding $15 \mu \mathrm{mol} / \mathrm{l}$ (hyperhomocysteinemia) has been shown to be associated with the development of atherosclerosis and greater risk for cardiovascular disease. Besides, hyperhomocysteinemia increases the risk of stroke, peripheral vascular disease and cognitive impairment $(7,8)$.

Chelation is the conventional recommendation for acute lead toxicity with encephalopathic damage, whereas treatment for chronic exposure to lead is still under investigation (4). The assumption that oxidative stress is involved in lead toxicity suggests that some antioxidants may play a role in the treatment of lead poisoning. One of them is $\beta$-carotene. In the human body, $\beta$-carotene is not only a stock form of vitamin A, but also associated with intercellular communication, interferons' activation, inhibition of cells proliferation and modulation of cells differentiating (9). As an antioxidant, $\beta$-carotene scavenges singlet oxygen physically without degradation and reacts with free radicals, such as the peroxyl, hydroxyl and superoxide radicals. Carotenoids have been shown to be able to decrease oxidative damage to DNA, lipids and proteins $(10,11)$. Some authors postulate $\beta$-carotene can reduce the incidence of many diseases, such as cancer, atherosclerosis, agerelated macular degeneration and multiple sclerosis (6). In the light of this, the aim of the study was to determine whether $\beta$-carotene administration reduces oxidative stress and homocysteine level in workers chronically exposed to lead.

\section{MATERIAL AND METHODS}

\section{Study population}

The exposed population included healthy male volunteers employed in zinc and lead works located in Miasteczko Śląskie, Poland. Participants were recruited by a specialist of occupational medicine during prophylactic medical examinations. All of them provided informed consent to the study. Their mean age was $41 \pm 8.57$. They were exposed to lead on average for $17 \pm 9.47$ years. The mean concentration of lead in the air at workplaces was $0.083 \pm 0.12 \mathrm{mg} / \mathrm{m}^{3}$. Blood levels of lead (PbB) and zincprotoporphyrin (ZPP) served as exposure markers.

The inclusion criteria were the following: occupational exposure to lead $(\mathrm{PbB}>20 \mu \mathrm{g} / \mathrm{dl}$ and $\mathrm{ZPP}$ $>2.5 \mu \mathrm{g} / \mathrm{g} \mathrm{Hb}$ ), no significant findings in physical examination and no past or present history of any chronic disease. Exclusion criteria included contraindications for $\beta$-carotene administration.

The examined population was randomly divided into 2 groups. Workers in the 1st group (reference group) had no any antioxidants, drugs, vitamins or dietary supplements administered, while workers in the 2nd group (CAR group) had $\beta$-carotene (Beta Karoten $^{\circ}$, Chance) administered orally in a dose of $10 \mathrm{mg}$ once a day. The study lasted 12 weeks. At the end of the study, participants were asked to return their empty pill boxes back to one of the study investigators to assess compliance with the treatment protocol.

Participants' blood was drawn two times: at the beginning of the study and after 12 weeks of supplementation. Biochemical analysis included markers of lead-exposure: $\mathrm{PbB}$ and $\mathrm{ZPP}$ levels in the blood. The level of malondialdehyde (MDA) in serum served as an 
oxidative stress biomarker. We also measured the level of Hcy and thiol groups (PSH) as well as the activity of superoxide dismutase (SOD) and its isoenzyme EC-SOD in serum served as an oxidative stress biomarker. Additively, we measured levels of copper $(\mathrm{Cu})$ and zinc $(\mathrm{Zn})$, the metal cofactors for EC-SOD.

The experimental protocol was approved by the Bioethics Committee of the Medical University of Silesia in Katowice (decission No. NN-6501-36/I/06).

\section{Laboratory procedures}

The whole blood was drawn by venipuncture. $10 \mathrm{ml}$ of blood was collected into plain tubes to obtain serum, while $15 \mathrm{ml}$ was placed in tubes containing ethylenediamine-tetraacetic disodium acid (EDTA) solution as an anticoagulant. Samples were stored in freezers at $-80^{\circ} \mathrm{C}$ for up to 3 months. $\mathrm{PbB}$ and $\mathrm{ZPP}$ levels were determined immediately after blood drawing.

$\mathrm{PbB}$ was analyzed in the whole blood by graphite furnace atomic absorption spectrophotometry using Unicam 929 and 939OZ Atomic Absorption Spectrometers with GF90 and GF90Z Graphite Furnaces. Data was expressed as $\mu \mathrm{g} / \mathrm{dl}$. The level of ZPP was measured using the Aviv Biomedical hematofluorometer model 206. Results were expressed in $\mu \mathrm{g}$ ZPP per a gram of hemoglobin $(\mu \mathrm{g} / \mathrm{g} \mathrm{Hb})$.

Lipid peroxidation was measured fluorometrically as 2-thiobarbituric acid-reactive substance (TBARS) in serum by Ohkawa (12). To improve the specificity of the method for MDA, we used sodium sulfate and butylated hydroxytoluene (BHT). TBARS values were expressed as malondialdehyde (MDA) equivalents. Tetraethoxypropane was used as the standard. Results were showed as $\mu \mathrm{mol} / \mathrm{l}$. The level of plasma Hcy was measured by enzyme-linked immunosorbent assay, using a kit by Axis-Shield diagnostics (UK) according to the manufacturer's instructions. Results were expressed as $\mu \mathrm{mol} / \mathrm{l}$.

The serum level of thiol groups was indicated by the method of Koster et al. (13) and displayed as $\mu$ moles per gram of protein $(\mu \mathrm{mol} / \mathrm{g} \mathrm{P})$. The amount of protein in the serum was measured by the buret method. The method of Oyanagui (14) was used to measure the activity of SOD in serum. In this method, xanthine oxidase produces superoxide anions which react with hydroxylamine forming nitric ions. The ions react with naphthalene diamine and sulfanilic acid generating a colored product. Concentration of this product is proportional to the amount of produced superoxide anions and negatively proportional to the activity of SOD. Absorbance was measured using
Shimadzu UV-1700 spectrophotometer at wavelength of $550 \mathrm{~nm}$. The activity of EC-SOD was measured using $\mathrm{KCN}$ as the inhibitor of this isoenzyme. The enzymatic activity of SOD was expressed in nitric units. The activity of SOD is equal to 1 nitric unit (NU) when it inhibits nitric ion production by $50 \%$. Activities of SOD were expressed as NU/ml. The concentrations of $\mathrm{Cu}$ and $\mathrm{Zn}$ in plasma were determined by atomic absorption spectrophotometer using an acetylene-air flame. The results were reported in $\mu \mathrm{g} / \mathrm{dl}$.

\section{Statistical analysis}

Statistical analysis was performed using Statistica 9.1 PL software. Statistical methods included the mean and standard deviation. Shapiro-Wilk's test was used to verify normality, whereas Levene's test was used to verify the homogeneity of variances. Statistical comparisons between groups were made by Student's t-test, a t-test with separate variance estimates, or a Mann-Whitney $U$ test. Differences $(\Delta)$ between the baseline and post-treatment values were determined for all subjects who had $\beta$-carotene administered and for subjects in the reference group. Then, differences $(\Delta)$ in the reference group were compared with the differences $(\Delta)$ in the group supplemented with $\beta$-carotene. Besides, in both groups, the mean and SD of the differences $(\Delta)$ were calculated. Thus, comparisons between the supplemented group and the reference group were made irrespective of different starting points at the baseline. Dependent variables were analyzed using Student's t-test and Wilcoxon's test. An a value of $\mathrm{p}<0.05$ was considered to be statistically significant.

\section{RESULTS}

At the beginning, the study consisted of 50 participants in the reference group and 35 participants in the CAR group. We further excluded 3 participants who had not been taking $\beta$-carotene according to the study protocol This left 49 subjects in the reference group and $33 \mathrm{sub}$ jects in the CAR group.

Any significant differences in age, years of work, body mass index (BMI) or smoking habits between the examined groups (Table 1) were not observed. Similarly, there were no differences in PbB and ZPP levels measured before supplementation. At the end of the study, the PbB level decreased significantly in the CAR group compared to baseline and to the reference group. However, supplementation with $\beta$-carotene did not affect ZPP levels (Table 1). 
Table 1. Epidemiologic parameters, the blood lead level (PbB), level of zinc protoporphyrin in the blood ( $\mathrm{ZPP}$ ) in $\mathrm{Pb}$-exposed population before and after 3 months of supplementation with $\beta$-carotene (the CAR group) vs. reference group

Tabela 1. Dane epidemiologiczne oraz stężenie we krwi ołowiu (PbB) i cynkoprotoporfiryny ( $\mathrm{ZPP})$ w grupie porównawczej oraz przed podawaniem i po 3-miesięcznym podawaniu $\beta$-karotenu grupie badanej (CAR)

\begin{tabular}{|c|c|c|c|c|c|}
\hline \multirow[t]{2}{*}{$\begin{array}{l}\text { Variable } \\
\text { Zmienna }\end{array}$} & \multicolumn{2}{|c|}{$\begin{array}{c}\text { Reference group } \\
\text { Grupa porównawcza } \\
(\mathrm{N}=49)\end{array}$} & \multicolumn{2}{|c|}{$\begin{array}{l}\text { CAR group } \\
\text { Grupa CAR } \\
(\mathrm{N}=33)\end{array}$} & \multirow[t]{2}{*}{$\mathrm{p}^{* *}$} \\
\hline & M & SD & M & SD & \\
\hline Age [years] / Wiek [w latach] & 40.90 & 8.25 & 41.50 & 9.58 & 0.425 \\
\hline Seniority [years] / Staż pracy [w latach] & 15.20 & 8.57 & 18.50 & 10.20 & 0.256 \\
\hline BMI & 27.10 & 3.21 & 27.40 & 4.22 & 0.917 \\
\hline Smoking habits / Palenie papierosów [\%] & 55.00 & & 42.00 & & 0.469 \\
\hline \multicolumn{6}{|l|}{$\mathrm{PbB}[\mu \mathrm{g} / \mathrm{dl}]$} \\
\hline before / przed & 44.10 & 9.30 & 44.90 & 8.15 & 0.354 \\
\hline after 3 months / po 3 miesiącach & 43.20 & 8.70 & 41.60 & 9.75 & 0.243 \\
\hline $\mathrm{p}^{*}$ & \multicolumn{2}{|c|}{0.981} & \multicolumn{3}{|c|}{0.023} \\
\hline$\Delta \mathrm{PbB}$ & -0.87 & 10.60 & -3.26 & 9.33 & 0.036 \\
\hline \multicolumn{6}{|l|}{$\mathrm{ZPP}[\mu \mathrm{g} / \mathrm{g} \mathrm{Hb}]$} \\
\hline before / przed & 8.71 & 4.84 & 7.85 & 3.61 & 0.548 \\
\hline after 3 months / po 3 miesiącach & 8.64 & 4.74 & 7.65 & 4.45 & 0.173 \\
\hline $\mathrm{p}^{*}$ & \multicolumn{2}{|c|}{0.758} & \multicolumn{3}{|c|}{0.151} \\
\hline$\Delta \mathrm{ZPP}$ & -0.07 & 4.08 & -0.20 & 3.50 & 0.297 \\
\hline
\end{tabular}

* Comparison between after and before observation or treatment / Porównanie wartości przed badaniem i po 3 miesiącach.

** Reference group vs. study (CAR) group / Grupa porównawcza vs grupa badana (CAR).

BMI - body mass index / wskaźnik masy ciała.

$\Delta$ - the difference between values obtained after and before observation or treatment / różnica między wartością po 3 miesiącach i przed badaniem.

M - mean / średnia, SD - standard deviation / odchylenie standardowe.

Table 2. The concentration of malondialdehyde (MDA), homocysteine (Hcy) and thiol groups (PSH) in serum in Pb-exposed population before and after 3 months of supplementation with $\beta$-carotene (the CAR group) vs. the reference group

Tabela 2. Stężenie dialdehydu malonowego (MDA), homocysteiny (Hcy) i grup tiolowych (PSH) w surowicy w grupie porównawczej oraz przed podawaniem i po 3-miesięcznym podawaniu $\beta$-karotenu grupie badanej (CAR)

\begin{tabular}{|c|c|c|c|c|c|}
\hline \multirow{2}{*}{$\begin{array}{l}\text { Variable } \\
\text { Zmienna }\end{array}$} & \multicolumn{2}{|c|}{$\begin{array}{l}\text { Reference group } \\
\text { Grupa porównawcza }\end{array}$} & \multicolumn{2}{|c|}{$\begin{array}{l}\text { CAR group } \\
\text { Grupa CAR }\end{array}$} & \multirow[t]{2}{*}{$\mathrm{P}^{* *}$} \\
\hline & M & $\mathrm{SD}$ & M & SD & \\
\hline \multicolumn{6}{|l|}{$\mathrm{MDA}[\mu \mathrm{mol} / \mathrm{l}]$} \\
\hline before / przed & 3.87 & 0.89 & 4.09 & 1.64 & 0.499 \\
\hline after 3 months / po 3 miesiącach & 3.96 & 0.91 & 3.44 & 1.33 & $<0.001$ \\
\hline $\mathrm{p}^{*}$ & \multicolumn{2}{|c|}{0.372} & \multicolumn{2}{|c|}{0.003} & \\
\hline$\Delta \mathrm{MDA}$ concentration / stężenie $\Delta \mathrm{MDA}$ & 0.08 & 1.08 & -0.65 & 1.16 & 0.005 \\
\hline \multicolumn{6}{|l|}{ Hcy $[\mu \mathrm{mol} / \mathrm{l}]$} \\
\hline before / przed & 15.40 & 4.21 & 16.40 & 4.26 & 0.612 \\
\hline after 3 months / po 3 miesiącach & 15.30 & 4.04 & 13.90 & 5.45 & 0.410 \\
\hline $\mathrm{p}^{*}$ & \multicolumn{2}{|c|}{0.879} & \multicolumn{2}{|c|}{0.068} & \\
\hline$\Delta$ Hcy concentration / stężenie $\Delta$ Hcy & -0.13 & 1.86 & -2.49 & 5.03 & 0.024 \\
\hline \multicolumn{6}{|l|}{$\mathrm{PSH}[\mu \mathrm{mol} / \mathrm{g}$ protein $]$} \\
\hline before / przed & 6.50 & 4.17 & 6.74 & 2.07 & 0.506 \\
\hline after 3 months / po 3 miesiącach & 6.11 & 4.13 & 7.80 & 3.38 & $<0.001$ \\
\hline $\mathrm{p}^{*}$ & \multicolumn{2}{|c|}{0.376} & \multicolumn{2}{|c|}{0.136} & \\
\hline$\Delta$ PSH concentration / stężenie $\Delta$ PSH & -0.39 & 2.96 & 1.05 & 3.48 & 0.016 \\
\hline
\end{tabular}

Abbreviations as in Table 1 / Skróty jak w tabeli 1. 
Table 3. The activities of superoxide dismutase (SOD) and EC-SOD isoenzyme in serum and the concentration of copper (Cu) and zinc $(\mathrm{Zn})$ in plasma in $\mathrm{Pb}$-exposed population before and after 3 months of supplementation with $\beta$-carotene (the CAR group) and observation in the reference group

Tabela 3. Aktywność dysmutazy ponadtlenkowej (SOD), jej izoenzymu EC-SOD w surowicy, stężenie miedzi (Cu) i cynku (Zn) w osoczu w grupie porównawczej oraz przed podawaniem i po 3-miesięcznym podawaniu $\beta$-karotenu grupie badanej (CAR)

\begin{tabular}{|c|c|c|c|c|c|}
\hline \multirow{2}{*}{$\begin{array}{l}\text { Variable } \\
\text { Zmienna }\end{array}$} & \multicolumn{2}{|c|}{$\begin{array}{l}\text { Reference group } \\
\text { Grupa porównawcza }\end{array}$} & \multicolumn{2}{|c|}{$\begin{array}{l}\text { CAR group } \\
\text { Grupa CAR }\end{array}$} & \multirow[t]{2}{*}{$\mathrm{P}^{* *}$} \\
\hline & M & SD & M & $\mathrm{SD}$ & \\
\hline before / przed & 14.20 & 3.12 & 15.00 & 4.43 & 0.223 \\
\hline after 3 months / po 3 miesiącach & 15.20 & 2.99 & 17.10 & 5.66 & 0.049 \\
\hline \multicolumn{6}{|l|}{ EC-SOD $[\mathrm{NU} / \mathrm{ml}$ serum] } \\
\hline before / przed & 6.63 & 2.02 & 7.41 & 2.81 & 0.082 \\
\hline after 3 months / po 3 miesiącach & 6.91 & 1.97 & 8.74 & 3.28 & 0.005 \\
\hline $\mathrm{p}^{*}$ & \multicolumn{2}{|c|}{0.543} & \multicolumn{2}{|c|}{0.022} & \\
\hline after 3 months / po 3 miesiącach & 76.00 & 11.40 & 74.50 & 13.90 & 0.423 \\
\hline $\mathrm{p}^{*}$ & \multicolumn{2}{|c|}{0.115} & \multicolumn{2}{|c|}{0.073} & \\
\hline$\Delta \mathrm{Cu}$ concentration / stężenie $\Delta \mathrm{Cu}$ & -2.54 & 10.50 & -3.54 & 11.70 & 0.989 \\
\hline \multicolumn{6}{|l|}{$\mathrm{Zn}[\mu \mathrm{g} / \mathrm{dl}]$} \\
\hline before / przed & 77.70 & 9.06 & 72.40 & 9.86 & 0.056 \\
\hline after 3 months / po 3 miesiącach & 73.30 & 13.30 & 72.50 & 9.00 & 0.590 \\
\hline $\mathrm{p}^{*}$ & \multicolumn{2}{|c|}{0.085} & \multicolumn{2}{|c|}{0.905} & \\
\hline$\Delta \mathrm{Zn}$ concentration / stężenie $\Delta \mathrm{Zn}$ & -4.36 & 16.40 & 0.06 & 10.20 & 0.306 \\
\hline
\end{tabular}

Abbreviations as in Table 1 / Skróty jak w tabeli 1.

After supplementation, the level of serum MDA significantly decreased compared to the baseline and to the reference group. A strong tendency toward lower values was observed in the case of Hcy level compared to the baseline. However, when compared to the reference group, Hcy level was significantly decreased (Table 2).

The level of thiol groups was significantly higher after supplementation with $\beta$-carotene compared to the reference group. Analogically, the activity of SOD and EC-SOD in serum was significantly higher compared to the baseline and to the reference group. The levels of $\mathrm{Cu}$ and $\mathrm{Zn}$ were not significantly changed after $\beta$-carotene administration (Table 2 and 3 ).

\section{DISCUSSION}

Homocysteine is a thiol-containing amino acid synthesized from methionine via demethylation (15). In the human body, Hcy impairs the function of vascular endothelial smooth muscle cells through the inhibition of nitric oxide synthesis, increased oxidative stress, proliferation of vascular smooth muscle cells and altered elasticity of the vascular wall. There are 2 pathways of Hcy metabolism. It can be remethylated or undergo transsulfuration to cysteine (16). In the transsulfuration pathway, the condensation of Hcy and serine to intermediate cystathionine is catalyzed by the enzyme cystathionine $\beta$-synthase, which is a pyridoxal 5'-phosphate-dependent heme-containing enzyme. However, in the remethylation pathway, Hcy is remethylated to methionine through the enzyme methionine synthase with vitamin $\mathrm{B}_{12}$, folate, and 5,10-methylenetetrahydrofolate reductase (MTHFR).

Because lead disrupts heme biosynthesis, suppressed activity of cystathionine $\beta$-synthase could be one mechanism that explains the observed association between blood lead and Hcy. At the same time, the variant enzyme MTHFR might cause lead to bind more to its 
active sites. In consequence, lead-induced impairment of the MTHFR function may be the second explanation for the relationship between elevated Hcy and lead levels. Besides, lead may bind to the thiol group of Hcy and hereby inhibit its metabolism. The interactions of lead with folate, vitamin $\mathrm{B}_{6}$, and vitamin $\mathrm{B}_{12}$ are also possible. To sum up, there are many possible mechanisms underlying elevated Hcy level in lead exposure that was reported in several studies $(8,16)$.

After having controlled for age, sex, race/ethnicity, alcohol intake, cigarette smoking, educational level and BMI, Schafer et al. (16) showed a linear association between blood lead and Hcy in older adults (Baltimore Memory Study). Similarly, in a study by Chia et al. (7), a significant association between blood lead and Hcy among factory workers in a Vietnamese population was detected after controlling for age and gender. Krieg et al. (17) and Yakub and Iqbal (18) showed analogous associations in adult U.S. and Pakistani civilians, respectively.

The present study indicates that supplementation with $\beta$-carotene decreases Hcy level in workers exposed to lead. At the beginning of the study, the mean Hcy levels were rather close to the normal level of $15 \mathrm{umol} / \mathrm{l}$ in both examined groups. In workers who were then given $\beta$-carotene, Hcy decreased to the normal values after 12 weeks of supplementation. At the same time, hyperhomocysteinemia in the reference group was still noted. To our best knowledge, there is no study in the available literature on the influence of $\beta$-carotene supplementation on Hcy level when administered separately. Some authors investigated the effect of $\beta$-carotenerich tomato juice, a mix of vegetables and fruits as well as fruit and vegetable juice concentrates on the blood levels of cardiovascular disease risk indicators, including Hcy (19-21). Due to different study protocols and interactions between administered antioxidants, the obtained results are inconsistent and difficult to interpret. Therefore, further investigations are necessary to explain how $\beta$-carotene influences Hcy level.

Antioxidant properties of $\beta$-carotene are better documented. However, there have only been few studies on the effect of $\beta$-carotene administration on the oxidative stress level in lead-exposure. In these studies, $\beta$-carotene was administered together with other antioxidants. In a study by Shastri et al. (22), a blue-green algae Spirulina fusiformis in a dose of $800 \mathrm{mg} / \mathrm{kg}$ body weight, containing $\beta$-carotene and SOD, enhanced the survival time in lead-exposed mice. In another study (23), $\beta$-carotene was administered concomitantly with vitamins and microelements for 4 weeks in lead-exposed workers. This intervention increased total antioxidant capacity (TAC) and modified activities of antioxidant enzymes.

The most widely used test for oxidative stress is the measurement of MDA, a product of lipid peroxidation (24). In the present study, we observed that therapy with $\beta$-carotene significantly decreased serum MDA level. These findings are probably due to the ability of $\beta$-carotene to react with lipid peroxyl radicals. This reaction theoretically may lead to the $\beta$-carotene depletion when its sources in a diet are inadequate. Consistently, Chlebda et al. (25) reported decreased levels of $\beta$ carotene by $29 \%$ in workers exposed to lead $(\mathrm{PbB}=35 \mu \mathrm{g} / \mathrm{dl})$ compared to the unexposed control group $(\mathrm{PbB}=5.2 \mu \mathrm{g} / \mathrm{dl})$.

The level of thiol groups is the 2nd measured parameter indirectly reflects oxidative stress intensity. In our previous study, we reported significantly decreased thiol groups level in a similar group of workers who were exposed to lead (26). Results of the present study indicate that $\beta$-carotene is efficient to restore the level of thiol groups. Therefore, basing on the obtained concentrations of MDA and thiol groups, it is possible to state that $\beta$-carotene is able to reduce oxidative stress when administered in lead-exposed workers. This reduction might be also caused by a significant decrease in the PbB level that was reported in the present study after $\beta$-carotene administration. Although, there is no evidence that $\beta$-carotene has chelating properties. Further investigations should be performed to explain such results.

According to several authors, antioxidant properties of $\beta$-carotene are controversial. For example, when $\beta$-carotene was administered in smokers, $18 \%$-increase in lung cancer incidence and increased mortality were reported (The Alpha-Tocopherol Beta-Carotene Cancer Prevention Study Group, 1994). Analogous results were shown after the supplementation of patients occupationally exposed to asbestos. Additively, increased frequency of intracerebral haemorrhage cases was noted in supplemented alcoholics (9).

Data indicates that beneficial antioxidant properties of $\beta$-carotene are manifested under low partial pressure of oxygen, while under high oxygen partial pressure the role of antioxidant is rather played by vitamin $\mathrm{E}$. This vitamin is also essential to protect $\beta$-carotene from conversion to a toxic peroxyl radical. At the same time, vitamin $\mathrm{C}$ reconverts $\beta$ carotene radical to its parent form. Therefore, under certain conditions, e.g., when there is a vitamin $\mathrm{E}$ or $\mathrm{C}$ deficiency, $\beta$-carotene could act as a pro-oxidant. This biphasic response of $\beta$-carotene explains the contradictory results of researches $(9,27-29)$. 
Lead-exposure induces expression and activity of SOD probably as a result of compensatory defense mechanisms against oxidative stress (30). After $\beta$-carotene administration, we observed a significant increase in serum SOD and EC-SOD activity compared to the baseline and to the reference group. Simultaneously, the levels of $\mathrm{Cu}$ and $\mathrm{Zn}$ remained unaltered after supplementation. Therefore, the reported increase of EC-SOD activity was probably not due to the interactions of lead with metal cofactors of the enzyme. Because products of lipid peroxidation could inactivate superoxide dismutase gene (Sod) by crosslinking or damaging DNA (31), elevated SOD activity may be rather a result of decreased lipid peroxidation by $\beta$-carotene.

\section{CONCLUSIONS}

Beta-carotene in a dose of $10 \mathrm{mg}$ a day administered orally to workers chronically exposed to lead decreased the level of atherogenic homocysteine and reduced oxidative stress measured as malondialdehyde level. Besides, the medication was well-tolerated with no evidence of adverse side effects.

Concluding, despite some controversies over antioxidant properties of $\beta$-carotene, our results indicate that its antioxidant action could provide some beneficial effects in lead-exposure independent of chelation.

\section{REFERENCES}

1. Flora G, Gupta D, Tiwari A. Toxicity of lead: A review with recent updates. Interdiscip Toxicol. 2012;5(2):47-58, http://dx.doi.org/10.2478/v10102-012-0009-2.

2. Malekirad AA, Oryan S, Fani A, Babapor V, Hashemi M, Baeeri M, et al. Study on clinical and biochemical toxicity biomarkers in a zinc-lead mine workers. Toxicol Ind Health. 2010;26(6):331-7, http://dx.doi.org/ $10.1177 / 0748233710365697$.

3. Trzcinka-Ochocka M, Jakubowski M, Raźniewska G. [Assessment of occupational exposure to lead in Poland]. Med Pr. 2005;56(5):395-404. Polish.

4. Patrick L. Lead toxicity, a review of the literature. Part 1: Exposure, evaluation, and treatment. Altern Med Rev. 2006;11(1):2-22.

5. Kasperczyk S, Dobrakowski M, Ostałowska A, Kasperczyk A, Wilczyński S, Wyparło-Wszelaki M, et al. Leadelevated activity of xanthine oxidase in lead-exposed workers. Med Pr. 2013;64(2):175-80, http://dx.doi.org/ 10.13075/mp.5893/2013/0013.
6. Hsu PC, Guo YL. Antioxidant nutrients and lead toxicity. Toxicology. 2002;180(1):33-44, http://dx.doi.org/ 10.1016/S0300-483X(02)00380-3.

7. Chia SE, Ali SM, Lee BL, Lim GH, Jin S, Dong NV, et al. Association of blood lead and homocysteine levels among lead exposed subjects in Vietnam and Singapore. Occup Environ Med. 2007;64(10):688-93, http://dx.doi.org/ 10.1136/oem.2006.030882.

8. Lee YM, Lee MK, Bae SG, Lee SH, Kim SY, Lee DH. Association of homocysteine levels with blood lead levels and micronutrients in the US general population. J Prev Med Public Health. 2012;45(6):387-93, http://dx.doi.org/ 10.3961/jpmph.2012.45.6.387.

9. Rutkowski M, Grzegorczyk K. Adverse effects of antioxidative vitamins. Int J Occup Med Environ Health. 2012;25(2):105-21, http://dx.doi.org/10.2478/S13382-0120022-x.

10. Agarwal M, Parameswari RP, Vasanthi HR, Das DK. Dynamic action of carotenoids in cardioprotection and maintenance of cardiac health. Molecules. 2012;17(4):4755-69, http://dx.doi.org/10.3390/molecules17044755.

11. Chapman MS. Vitamin A: History, current uses, and controversies. Semin Cutan Med Surg. 2012;31(1):11-6, http://dx.doi.org/10.1016/j.sder.2011.11.009.

12. Ohkawa H, Ohishi N, Yagi K. Assay for lipid peroxides in animal tissues by thiobarbituric acid reaction. Anal Biochem. 1979;95(2):351-8, http://dx.doi.org/10.1016/00032697(79)90738-3.

13. Koster JF, Biemond P, Swaak AJ. Intracellular and extracellular sulphydryl levels in rheumatoid arthritis. Ann Rheum Dis. 1986;45(1):44-6, http://dx.doi.org/10.1136/ ard.45.1.44.

14. Oyanagui Y. Reevaluation of assay methods and establishment of kit for superoxide dismutase activity. Anal Biochem. 1984;142(2):290-6, http://dx.doi.org/10.1016/ 0003-2697(84)90467-6.

15. Ventura P, Panini R, Abbati G, Marchetti G, Salvioli G. Urinary and plasma homocysteine and cysteine levels during prolonged oral $\mathrm{N}$-acetylcysteine therapy. Pharmacology. 2003;68(2):105-14, http://dx.doi.org/10.1159/000069535.

16. Schafer JH, Glass TA, Bressler J, Todd AC, Schwartz BS. Blood lead is a predictor of homocysteine levels in a population-based study of older adults. Environ Health Perspect. 2005;113(1):31-5, http://dx.doi.org/10.1289/ ehp.7369.

17. Krieg Jr. EF, Butler MA, Chang MH, Liu T, Yesupriya A, Lindegren ML, et al. Lead and cognitive function in ALAD genotypes in the third National Health and Nutrition Examination Survey. Neurotoxicol Teratol. 2009;31(6): 364-71, http://dx.doi.org/10.1016/j.ntt.2009.08.003. 
18. Yakub M, Iqbal MP. Association of blood lead ( $\mathrm{Pb}$ ) and plasma homocysteine: A cross sectional survey in Karachi, Pakistan. PLOS One. 2010;5(7):e11706, http://dx.doi.org/ 10.1371/journal.pone.0011706.

19. Broekmans WM, Klöpping-Ketelaars IA, Schuurman CR, Verhagen $H$, van den Berg H, Kok FJ, et al. Fruits and vegetables increase plasma carotenoids and vitamins and decrease homocysteine in humans. J Nutr. 2000;130(6):1578-83.

20. Kawashima A, Madarame T, Koike H, Komatsu Y, Wise JA. Four week supplementation with mixed fruit and vegetable juice concentrates increased protective serum antioxidants and folate and decreased plasma homocysteine in Japanese subjects. Asia Pac J Clin Nutr. 2007;16(3):411-21.

21. Shidfar F, Froghifar N, Vafa M, Rajab A, Hosseini S, Shidfar $S$, et al. The effects of tomato consumption on serum glucose, apolipoprotein B, apolipoprotein A-I, homocysteine and blood pressure in type 2 diabetic patients. Int J Food Sci Nutr. 2011;62(3):289-94, http://dx.doi.org/ 10.3109/09637486.2010.529072.

22. Shastri D, Kumar M, Kumar A. Modulation of lead toxicity by Spirulina fusiformis. Phytother Res. 1999;13(3): 258-60.

23. Machartova V, Racek J, Kohout J, Senft V, Trefil L. [Effect of antioxidant therapy on indicators of free radical activity in workers at risk of lead exposure]. Vnitr Lek. 2000;46(8):444-6. Czech.

24. Antonio-García MT, Massó-Gonzalez EL. Toxic effects of perinatal lead exposure on the brain of rats: Involvement of oxidative stress and the beneficial role of antioxidants. Food Chem Toxicol. 2008;46(6):2089-95, http://dx.doi.org/ 10.1016/j.fct.2008.01.053.
25. Chlebda E, Antonowicz-Juchniewicz J, Andrzejak R. [The effect of occupational exposure to heavy metals and arsenic on serum concentration of carotenoids in copper foundry workers]. Med Pr. 2004;55(5):389-401. Polish.

26. Kasperczyk S, Słowińska-Łożyńska L, Kasperczyk A, Wielkoszyński T, Birkner E. The effect of occupational lead exposure on lipid peroxidation, protein carbonylation, and plasma viscosity. Toxicol Ind Health. 2013 [cited 2013 Aug 4]. Available from: http://www.ncbi.nlm.nih. gov/pubmed/23709227.

27. Böhm F, Edge R, Truscott TG. Interactions of dietary carotenoids with singlet oxygen $\left(\mathrm{O}_{2}\right)$ and free radicals: Potential effects for human health. Acta Biochim Pol. 2012;59(1):27-30.

28. Mortensen A, Skibsted LH, Truscott TG. The interaction of dietary carotenoids with radical species. Arch Biochem Biophys. 2001;385(1):13-9, http://dx.doi.org/10.1006/ abbi.2000.2172.

29. Tsuchihashi H, Kigoshi M, Iwatsuki M, Niki E. Action of $\beta$-carotene as an antioxidant against lipid peroxidation. Arch Biochem Biophys. 1995;323(1):137-47, http://dx.doi.org/10.1006/abbi.1995.0019.

30. Kasperczyk A, Machnik G, Dobrakowski M, Sypniewski D, Birkner E, Kasperczyk S. Gene expression and activity of antioxidant enzymes in the blood cells of workers who were occupationally exposed to lead. Toxicology. 2012;301(1-3):79-84, http://dx.doi.org/10.1016/ j.tox.2012.07.002.

31. Sivaprasad R, Nagaraj M, Varalakshmi P. Combined efficacies of lipoic acid and meso-2,3-dimercaptosuccinic acid on lead-induced erythrocyte membrane lipid peroxidation and antioxidant status in rats. Hum Exp Toxicol. 2003;22(4):183-92, http://dx.doi.org/ 10.1191/0960327103ht335oa.

\footnotetext{
The use of the article "The influence of $\beta$-carotene on homocysteine level and oxidative stress in lead-exposed workers" is permitted under license conditions of Creative Commons Attribution-NonCommercial 3.0 (also known as CC-BY-NC), available at http://creativecommons.org/licenses/by-nc/3.0/pl/ or another language version of this license or any later version of this license published by Creative Commons / Zezwala się na korzystanie $\mathrm{z}$ artykułu „Wpływ $\beta$-karotenu na stężenie hemocysteiny i nasilenie stresu oksydacyjnego u pracowników narażonych na związki ołowiu" na warunkach licencji Creative Commons Uznanie autorstwa - Użycie niekomercyjne 3.0 (znanej również jako CC-BY-NC), dostępnej pod adresem http://creativecommons.org/licenses/by-nc/3.0/pl/ lub innej wersji językowej tej licencji lub którejkolwiek późniejszej wersji tej licencji, opublikowanej przez organizację Creative Commons.
} 